\title{
INCIDENCE OF METOPISM IN EASTERN INDIA
}

\section{Banani Kundu *1, Ishita Ghosh 2, Pranab Mukherjee ${ }^{3}$, Alpana DE 4.}

${ }^{{ }^{*} 1}$ Assistant Professor, Department of Anatomy, R. G. Kar Medical College and Hospital, Kolkata, West Bengal, India.

${ }^{2}$ Demonstrator, Department of Anatomy, R. G. Kar Medical College and Hospital, Kolkata, West Bengal, India.

${ }^{3,4}$ Professor, Department of Anatomy, R. G. Kar Medical College and Hospital, Kolkata, West Bengal, India.

\section{ABSTRACT}

Background: The Metopic Suture is a suture seen between the two halves of frontal bones which ossifies in membrane from the two primary centres. The fusion of the metopic suture starts at around eighteen months after birth and completed by six years of age. Persistence of this suture in adult is called metopism. It may be misinterpreted as fracture in x-ray.

Materials and Methods: This study was conducted with 133 human adult dry skulls. They were inspected at norma frontalis for presence of metopic suture. They were classified as complete and incomplete. The incomplete ones were again classified as ' $\mathrm{V}$ ','U','Y' and linear type.

Observation and Results: Out of 133 skulls 84 were found to have no metopic suture, one had complete suture (extending from glabella upto bregma ),14 skulls were manifested to have ' $V$ ' shaped suture,11 skulls were discovered to have ' $U$ ' shaped suture, 6 skulls were revealed to have ' $Y$ ' shaped suture and remaining 17 showed linear metopic suture in the midline.

Conclusion: The present study was conducted to note the incidence of metopism in adult skull which may be useful in the field of Neurosurgery, Radiology and Forensic Medicine.

KEY WORDS: Adult skull, Metopic suture, Metopism, Ossifcation.

Address for Correspondence: Dr. Banani Kundu, Assistant Professor, Department of Anatomy, R. G. Kar Medical College and Hospital, Kolkata, West Bengal 700004, India.

E-Mail: dr.bmitra@yahoo.com

\section{Access this Article online}

\begin{tabular}{|c|c|c|}
\hline \multirow{2}{*}{$\begin{array}{l}\text { Quick Response code } \\
\qquad \text { 口isp }\end{array}$} & \multicolumn{2}{|c|}{$\begin{array}{l}\text { Web site: International Journal of Anatomy and Research } \\
\qquad \text { ISSN 2321-4287 } \\
\text { www.ijmhr.org/ijar.htm }\end{array}$} \\
\hline & $\begin{array}{l}\text { Received: } 22 \text { Feb } 2017 \\
\text { Peer Review: } 22 \text { Feb } 2017\end{array}$ & $\begin{array}{l}\text { Accepted: } 03 \text { Apr } 2017 \\
\text { Published (O): } 30 \text { Apr } 2017\end{array}$ \\
\hline & Revised: None & Published (P): 30 Apr 2017 \\
\hline
\end{tabular}

\section{INTRODUCTION}

Skull is made up of cranial bones which are held together by fibrous joint named suture. The frontal bone is unpaired bone of the skull forming the forehead. Glabella is the median elevation between two superciliary arches and bregma is the meeting point of sagittal and coronal suture. There is a suture line present between the two halves of frontal bone which generally fuses in childhood. When the suture line fails to close metopism persists in adult skull. When it extends from bregma to nasion it is called complete metopic suture and if not present throughout then it is known as incomplete.

According to Manzanares et al [1] the metopic suture was ossified in membrane from two 
primary centres and fused with the inner surface of the skull by chondroid tissue.

Warwick and Williams reported that the metopic suture was usually obliterated by eight years. Piersol et al [2] concluded that the metopic suture was disappeared by the end of fourth year. But Moore, Dalley, Agur also supported the theory of closure of metopic suture by eight years [3]. Abnormal growth of skull bone is responsible for persistence of metopic suture in adult. This abnormality of growth of skull was due to hereditary influence, hormonal cause, atavism, cranial malformation and hydrocephalus. The incidence of metopic suture varies in different races- $4-5 \%$ in Yellow races, $7-10 \%$ in Europeans and $1 \%$ in African skulls [4]. Das et al reported the incidence of metopism in Indian skulls was $27.98 \%$ [5] whereas according to agarwall $40.83 \%$ skulls showed metopism [6]. Incidence of metopism in Indian skulls were low compared to the Alpine skulls (63.2\%) but much higher compared to Australian (1\%) and Scottish skulls (9.5\%) [7].

Study of Metopism is important for paleodemography and also for medico-legal issues in Forensic Medicine. It is also important for radiologists to avoid misinterpretation of metopic suture as fracture line.

\section{MATERIALS AND METHODS}

The study was conducted on 133 adult dry human skulls taking from the osteology museum of the Department of Anatomy, R. G. Kar Medical College. Fractured skulls were discarded and the study was carried out only on intact skulls. Each skulls was thoroughly inspected to find out the persistance of metopic suture. The skulls were divided into following groups-

1. Normal skull without metopic suture

2. Normal skull with metopic suture -

a)Complete, b) Incomplete

Incomplete suture were classified according to their shape such as Linear, $U$ shaped, $V$ shaped and $Y$ shaped.

The incidence of complete and incomplete metopic suture were calculated and the data obtained were compared with the previous studies.

\section{OBSERVATION AND RESULTS}

Out of 133 dry human skulls studied 84 skulls were found to have no metopic suture. Complete suture was found in only one skull $(0.82 \%)$, and rest showed incomplete sutures. Among them 14 skulls $(11.47 \%)$ have ' $V$ ' shaped suture,11 skulls $(9.02 \%)$ observed to have ' $U$ ' shaped suture, 6 skulls (4.92\%) revealed ' $Y$ ' shaped and rest i.e 17 skulls (13.94\%) have linear type of metopic suture.

Fig. 1: 'V' type Metopic Suture.

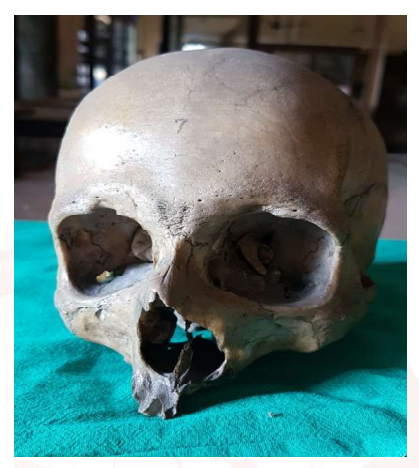

Fig. 3: 'COMPLETE' type of Metopic suture.

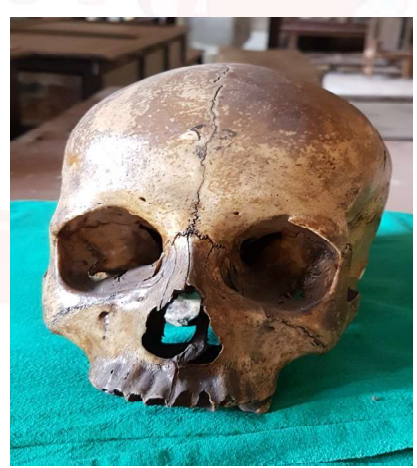

Fig. 2: 'U' type Metopic Suture

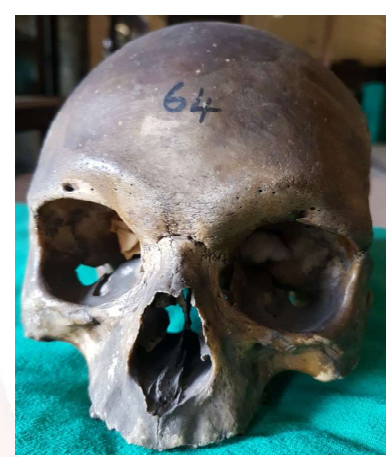

Fig. 4: ' INCOMPLETE LINEAR' type of Metopic Suture.
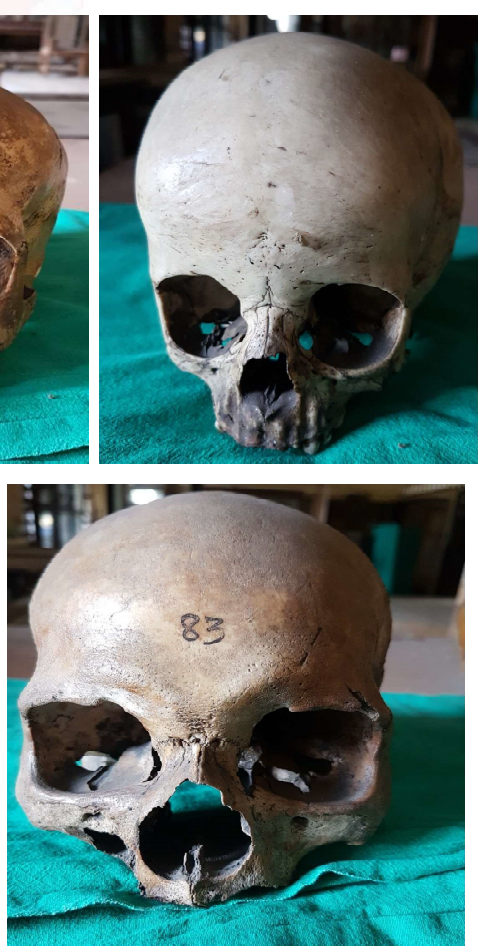

Table 1: Occurrence of metopic suture in 133 skulls and their percentage.

\begin{tabular}{|c|c|c|c|}
\hline S. No & Shape of Metopic suture & $\begin{array}{c}\text { Number of } \\
\text { skulls }\end{array}$ & Percentage \\
\hline 1 & Absent metopic suture & 84 & 63.15 \\
\hline 2 & Complete suture & 1 & 0.82 \\
\hline 3 & V shaped & 14 & 11.47 \\
\hline 4 & U shaped & 11 & 9.02 \\
\hline 5 & Y shaped & 6 & 4.92 \\
\hline 6 & Linear & 17 & 13.94 \\
\hline
\end{tabular}


Table 2: Variation in incidence of metopism in different regions of India.

\begin{tabular}{|c|c|c|c|}
\hline S. No & Regions of India & Workers & Percentage \\
\hline 1 & Punjab & Jit \& Shah et al (1948) & 5 \\
\hline 2 & Uttar Pradesh & Das et al (1973) & 3.31 \\
\hline 3 & Kanpur & Agarwal et al (1979) & 2.66 \\
\hline 4 & $\begin{array}{c}\text { Maharastra and } \\
\text { Western India }\end{array}$ & W R Pankaj et al (2014) & 1.25 \\
\hline 5 & South India & Pilli N (2013) & 4.25 \\
\hline 6 & Eastern India & Present Study & 3.68 \\
\hline
\end{tabular}

Table 3: Racial variation in the incidence of metopism.

\begin{tabular}{|c|c|c|c|}
\hline S. no & Authors & Population & Incidence \\
\hline 1 & Bryce & European & 8.7 \\
\hline 2 & Bryce & Mongolian & 5.1 \\
\hline 3 & Bryce & Negro & 1.2 \\
\hline 4 & Bryce & Australian & 1 \\
\hline 5 & Bryce & Scottish & 9.5 \\
\hline 6 & Jit \& Shah & Indian-Punjab & 5 \\
\hline 7 & Woo & Mongolian & 10 \\
\hline 8 & Woo & Negro & 2 \\
\hline 9 & Breathnach & European & $7-10$ \\
\hline 10 & Breathnach & Yellow Race & $4-5$ \\
\hline 11 & Breathnach & African & 1 \\
\hline 12 & Romanes & European & $0-8$ \\
\hline 13 & Das & Indian-UP & 3.31 \\
\hline 14 & Agarwal & Indians & 2.66 \\
\hline 15 & Ajmani & Nigerian & 3.4 \\
\hline 16 & B.V.Murlimanju & Indians & 1.2 \\
\hline 17 & Hussain Saheb S & Indian-South & 3.2 \\
\hline 18 & Chanwit Maneenin & North-East, Thi & 10.12 \\
\hline 19 & Present Study & Indian-East & 3.68 \\
\hline
\end{tabular}

\section{DISCUSSION}

The study revealed that incidence of metopism in East Indian adult population is $3.68 \%$ which was comparable to other parts of India. Infact the studies carried on Indian population have revealed that incidence of metopism in different region of country vary between 2.66$5 \%[5,6,8]$. Murlimanju observed incidence of metopism in Indian population- $64.1 \%$ [9].Hussain Saheb $S$ et al reported incidence of metopism in South Indian skulls as 29.6\% [10].

Ajmani M.L.et al observed the presence of metopic suture in $34.97 \%$ in Nigerian populations [11].

Abnormal growth of cranial bones, hydrocephalus, growth retardation, sexual influence, hereditary, atavism, stenocrotaphia (abnormal narrowing of skull), plagiocephaly (cranial malformation causing a twisted and asymmetrical head due to synostosis of cranial suture), Scaphocephaly (deformed head projecting forward keel of boat), mechanical and hormonal dysfunction may be the contributory factors of metopism [12]. Apert syndrome may be associated with impaired closure of metopic suture [13].

\section{CONCLUSION}

The present study was carried out in 133 adult human dry skulls. Out of which no metopic suture was observed in 84 skulls, 14 had ' $V$ ' shaped,11 with ' $U$ ' shaped, 6 had ' $Y$ ' shaped and 17 with 'Linear' suture. Metopism was observed in $40.17 \%$ of skulls.

A linear vertical fracture of frontal bone may be misdiagnosed as persistant metopic suture. Thus anatomical knowledge of metopic suture is helpful for both Radiologists and Neurosurgeons for diagnosis and treatment of head injury patients. Previously no such study involving Eastern Indian population was carried out. So the present study is unique as it may provide useful information in both diagnostic and treatment purpose. More extensive study in future is required to get conclusive data.

\section{ACKNOWLEDGEMENTS}

The authors express their heartfelt gratitude to all the members of the Department of Anatomy, R G Kar Medical College, Kolkata for their kind cooperation and generosity in the conduct of this study.

\section{Conflicts of Interests: None}

\section{REFERENCES}

[1]. Manzanares,M C, Goret-nicaise, M, Dhen, A. Metopic sutural closure in the human skull. J.Anat., 1988;161:203-15.

[2]. Piersol, G. A. Human Anatomy, $5^{\text {th }}$ ed. 1916, Philadelphia: Lippincott.

[3]. Moore, Dalley, Agur- Clinically oriented Anatomy; Wolters Kluwer, Lippincott Williams \& Wilkins $6^{\text {th }}$ ed pp 840.

[4]. Breathnach A.S. Frazer's Anatomy of the Human Skeleton, $5^{\text {th }}$ ed.1958; London: Churchill.

[5]. Das A.C, Saxena R.C \& Beg M.A.Q. Incidence of metopic suture in U.P. subjects. Journal of Anatomical Society of India 1973;22:40. 
[6]. Agarwal S.K, Malhotra V.K \& Tewari S.P. Incidence of metopic suture in adult Indian crania. Acta anatomica 1979;105,469474.

[7]. Bryce et al. Observations on metopism.J.Anat. 1917;51:153-66.

[8]. Jit, I. \& Shah, M A. Incidence of frontal or metopic suture amongst Punjabi adults. Indian Medical Gazette 1948;83:507.

[9]. Murlimanju B.V.et al, Median Frontal Sutures - Incidence, Morphology and Their Surgical, Radiological Importance. Turkish Neurosurgery 2011;21(4): 489-493.

[10]. Hussain Saheb S et al. Incidence of metopic suture in adult South Indian skulls. J Biomed Sci and Res, 2010;2(4):223-226.
[11]. Ajmani ML, Mittal RK, Jain SP. Incidence of metopic suture in adult Nigerian skulls. J Anat 1983;137:177183.

[12]. Del Sol M, Binvignat O, Bolini PD, Prates JC. Metopism in Brazilians. Rev Paul Med 1989;107:105107.

[13]. Faro C, Chaoui R, Wegrzyn P, Levaillant JM, Benoit B, Nicolaides $\mathrm{KH}$ : Metopic suture in fetuses with Apert syndrome at 22-27 weeks of gestation. Ultrasound Obstet Gynecol 2006;27:28-33.

How to cite this article:

Banani Kundu, Ishita Ghosh, Pranab Mukherjee, Alpana DE. INCIDENCE OF METOPISM IN EASTERN INDIA. Int J Anat Res 2017;5(2.1):3727-3730. DOI: 10.16965/ijar.2017.158 